\title{
O ACESSO À JUSTIÇA E A QUARTA PAREDE: A AUDIÊNCIA DO ARTIGO 334 DO CPC DE 2015 COMO ESTRATÉGIA DEMOCRÁTICA?
}

\section{THE ACESS TO JUSTICE AND THE FOURTH WALL: CAN THE AUDIENCE OF ARTICLE 334 OF THE CPC 2015 BE A DEMOCRATIC STRATEGY?}

\author{
${ }^{1}$ Elaine Harzheim Macedo \\ ${ }^{2}$ Marina Damasceno
}

\section{Resumo}

O presente artigo objetivou analisar o fenômeno da quarta parede, próprio das artes cênicas, no processo quando o jurisdicionado é ignorado pelos operadores e deixado como mero espectador silencioso a resultar em falta de efetividade ao acesso à justiça porque não houve participação do jurisdicionado. Utilizando-se de análise dedutiva, buscou-se averiguar se a audiência preliminar de autocomposição do artigo 334 do CPC age como estratégica democrática para proporcionar papel mais ativo ao jurisdicionado para quebrar essa quarta parede. Concluiu-se que a referida audiência se configura como ferramenta democrática para maior integração entre todos os agentes responsáveis pela composição do conflito.

Palavras-chave: Acesso à justiça, Quarta parede, Audiência preliminar, Mediação, Conciliação

\section{Abstract/Resumen/Résumé}

This article aimed to analyse the fourth wall in the process when the person under jurisdiction is ignored by operators and left as a quiet spectator what results in lack of effective access to justice. Using deductive analysis, sought to ascertain whether the preliminary hearing of composition of artigo 334 of the CPC acts as democratic strategic to provide more active role to the person under jurisdiction for breaking that fourth wall. It was concluded that this audience is configured as a democratic tool for greater integration between all agents responsible for the composition of the conflict.

Keywords/Palabras-claves/Mots-clés: Acess to justice, Fourth wall, Preliminary hearing, Conflict mediation, Conciliation

\footnotetext{
${ }^{1}$ Doutora em Direito pela Universidade do Vale do Rio dos Sinos, UNISINOS - Porto Alegre - RS, (Brasil). Professora da Graduação, Mestrado e Doutorado em Direito na Pontifícia Universidade Católica do Rio Grande do Sul, PUCRS - RS, (Brasil). Presidente do Instituto Gaúcho de Direito Eleitoral. Advogada. E-mail: elaine@fhm.adv.br

${ }^{2}$ Mestranda em Direito pela Pontifícia Universidade Católica do Rio Grande do Sul, PUCRS - RS, (Brasil).E-mail: damasceno.ma@gmail.com
} 


\section{INTRODUÇÃO: A QUARTA PAREDE NO PODER JUDICIÁRIO}

Com origem no teatro, o termo quarta parede refere-se a uma parede invisível que imaginariamente divide a plateia dos atores. Este seria o motivo pelo qual a plateia enxerga os atores, mas eles, por sua vez, não conseguem fazê-lo (MANGAN, 2013, p. 172). As laterais do palco representam duas paredes; o fundo, uma terceira parede; a quarta parede equivaleria à uma divisão imaginária na parte frontal do palco. Assim, como os atores, durante o espetáculo, não sabem da existência de um público que os assiste, há um distanciamento entre ambos.

Quando a quarta parede é quebrada, o ator dirige-se diretamente ao público, mas nenhum dos dois deixa de ser o que é, ou seja, ator e espectador. Nesse sentido, há uma proposta educativa e filosófica, porquanto tanto para o público como para aquele que encena pretendese que desenvolvam uma atitude de questionar e refletir sobre o que fazem e o que veem. A plateia deixa de ser mera espectadora, pois ela se sente parte do que ocorre dentro do espetáculo; não mais um elemento inútil (MIRANDA, 2011, p. 38-39).

É possível, por analogia, transportar o universo teatral para o mundo jurídico. Os operadores do direito, sejam eles juízes, promotores, advogados, servidores da justiça, equivaleriam aos atores. Os jurisdicionados são a plateia que atua como espectador dos atos processos. O processo, dessa forma, torna-se o espetáculo.

Diferentemente do mundo teatral, contudo, o mundo jurídico insiste na existência da quarta parede entre os operadores do direito e os litigantes, resistindo à sua derrubada. No desenrolar dos atos processuais, os atores jurídicos agem entre si, deixando as partes como meras espectadoras do que ocorre no processo. Sabe-se que o processo visa a uma sentença de mérito, a qual influenciará diretamente os litigantes envolvidos em determinado processo. Todavia, muitas vezes a sentença é prolatada e a própria parte não entende o real significado de seu conteúdo. É possível, por exemplo, presenciar em audiências, quando prolatada a sentença no local, a parte indagando seu procurador: ganhamos? Esse retrato representa um divorciamento entre os que devem prestar jurisdição e os que são seus destinatários, deslegitimando a decisão. Uma decisão, que interfere na vida e no patrimônio jurídico dos 
jurisdicionados, há de se legitimar - irrelevante sua legalidade - na força de sua aceitação, de sua absorção, o que exige uma participação mais efetiva e real do jurisdicionado.

A Constituição da República Federativa do Brasil de 1988 (CRFB) (BRASIL, 1988) trouxe uma gama de princípios, os quais influenciaram as mais diversas áreas do direito. Nesse sentido, é possível afirmar a existência de uma constitucionalização do processo civil. O próprio Código de Processo Civil (CPC) de 2015 (BRASIL, 2015) trouxe em seus doze primeiros artigos normas fundamentais a guiarem a interpretação dos demais artigos do referido diploma legal.

$\mathrm{O}$ princípio do acesso à justiça encontra-se positivado tanto na $\mathrm{CRFB}^{1}$ (BRASIL, 1988), quanto no Novo CPC $^{2}$ (BRASIL, 2015). A partir das explicações concernentes à quarta parede no Poder Judiciário, questiona-se, assim, o real significado do princípio do acesso à justiça. Afinal, de que serve o jurisdicionado alcançar o Poder Judiciário se não passa de um mero espectador perdido em meio ao espetáculo protagonizado exclusivamente pelos operadores do direito?

Destarte, a partir de uma metodologia dedutiva ${ }^{3}$, partindo-se de uma premissa maior e mais genérica e uma menor e mais específica, através de extensa pesquisa bibliográfica, buscaram-se conclusões acerca de possíveis estratégias a serem utilizadas na quebra da quarta parede, dando efetivadade ao princípio do acesso à justiça, especialmente, a audiência proposta no artigo $334^{4}$ do Código de Processo Civil, a democratizar as relações estabelecidas entre os personagens da cena judiciária e seus destinatários.

\section{O CÓDIGO DE PROCESSO CIVIL DE 2015 E O PROCESSO DEMOCRÁTICO}

A CRFB (BRASIL, 1988) estabeleceu como pedra basilar do Estado brasileiro o regime democrático.

\footnotetext{
1 A CRFB em seu artigo. 5', inciso XXXV, dispõe que "a lei não excluirá da apreciação do Poder Judiciário lesão ou ameaça a direito" (BRASIL, 1988).

2 Da mesma forma, o artigo $3^{\text {o }}$ da Lei n. 13.105/2015, “Art. $3^{\circ}$. Não se excluirá da apreciação jurisdicional

ameaça ou lesão a direito" (BRASIL, 2015).

3 Segundo Orides Mezzaroba e Cláudula Servilha Monteiro, o referido método inicia com argumentos gerais para chegar a argumentos particulares (2014, p. 91-92).

4 Art. 334. Se a petição inicial preencher os requisitos essenciais e não for o caso de improcedência liminar do pedido, o juiz designará audiência de conciliação ou de mediação com antecedência mínima de 30 (trinta) dias, devendo ser citado o réu com pelo menos 20 (vinte) dias de antecedência (BRASIL, 2015).
} 
Democracia não é atributo, dever ou objetivo exclusivo do Poder Executivo ou do Poder Legislativo, cumprindo também ao Poder Judiciário a sua concretização, interna no que toca à auto-organização de suas instituições, e, o que mais revela, no exercício de sua função precípua de julgar os conflitos e afirmar a jurisdição constitucional. A soberania popular, contemplada no parágrafo único do artigo $1^{\circ}$ da CRFB (BRASIL, 1988), vale para os três poderes, estendendo-se ao processo judicial, o qual, por derradeiro, compreende o exercício da atividade do Poder Judiciário na sua função de administração da justiça do caso concreto.

O CPC de 2015 (BRASIL, 2015) veio, a boa hora, construir um modelo de processo afeito - ou pelo menos a tanto procura alcançar - à soberania popular, instituindo um processo constitucional a partir de vetores determinantes, o que se denota já no seu preâmbulo, cujo Livro I trata das Normas Processuais Civis, adentrando o Capítulo I nas normas fundamentais do processo civil. O comprometimento da novel legislação processual civil com um processo constitucionalizado e democrático é uterino, talvez o seu maior mérito.

As palavras de Sérgio Gilberto Porto, ao comentar o então Projeto de Lei n. 8.046/2010, já vocacionavam a que vinha o novo Código:

\begin{abstract}
O artigo primeiro do projeto do novo CPC, sensível a realidade antes exposta, com clareza invulgar, estabelece que o processo civil contemporâneo deverá ser compreendido a partir de determinados primados constitucionais e que estes, mais do que antes, devem presidir claramente os destinos do futuro processo civil brasileiro. Ao assim se posicionar, longe de dúvida, o projeto traduz a vontade de que o processo seja instrumento de realização dos propósitos constitucionais e não apenas como instrumento de realização do direito material infraconstitucional. Há, pois, no projeto, clara opção ideológica e indiscutível norte fixado em favor da idéia de intensa constitucionalização do processo civil coevo. Isso equivale a dizer que devemos, uma vez transformado em lei o projeto, proceder a leitura do sistema processual sob a óptica da Constituição. Verdadeiramente emoldurar o processo civil coetâneo à Constituição Federal, agora, entretanto, por determinação expressa. Para aqueles que acompanham atentos a evolução do direito processual esta opção do projeto não se constitui em novidade e sequer necessitaria constar expressamente, haja vista que já de alguns anos para cá se percebe esta clara tendência no direito brasileiro e chega a se apontar existência de um movimento de "constitucionalização do direito", como se o direito brasileiro pudesse ser compreendido de outro modo que não alinhado com a Constituição Federal (2012, p. 26).
\end{abstract}

Nesse fio, é possível, a partir das normas fundamentais processuais, estabelecer como principais vetores do novo processo civil, a construção de um processo voltado fundamentalmente para as soluções consensuais, inclinando-se o pêndulo, historicamente em movimento, em favor da resolução do conflito através de composições alternativas e de 
caráter consensual, como a mediação e a conciliação, remetendo o processo adversarial para um segundo plano, como última opção; e mais, um processo dialogado, inspirado pelo contraditório pleno e substancial, onde a voz dos contendores seja ouvida, com o poder de influenciar a decisão, que há de ser fundamentada no âmbito do conflito e levando em consideração todas as teses, de fato e de direito, arguidas. Um modelo assim arquitetato, torna-se um processo mais participativo, mais democrático, mais policentrista e menos impositivo, imperial e concentrado nas mãos do julgador. Ao fim e ao cabo, o processo passa a ser um espaço democrático, predominantemente jurídico, de construção do direito do caso concreto.

O primeiro passo para a estruturação desse paradigma forjado na CRFB (BRASIL, 1988) e no CPC de 2015 (BRASIL, 2015) é o acesso à Justiça - objeto específico deste estudo. Embora consolidado na doutrina e na jurisprudência pátria, ainda construída sob a égide do Código revogado, sua revigoração se faz necessária.

\title{
3 O ACESSO À JUSTIÇA
}

O princípio do acesso à justiça, de tradição do Estado liberal, veio revigorado expressamente na CRFB (BRASIL, 1988) em seu artigo $5^{\circ}$, inciso XXV, sendo elevado à garantia constitucional.

No que tange à distinção entre direitos e garantias fundamentais, Ingo Wolfgang Sarlet explica, adotando a expressão direitos-garantia ou princípios garantia:

\begin{abstract}
A própria distinção entre direitos e garantias, por sua vez, não pode mascarar a circunstância de que, em termos gerais, as garantias, embora evidentemente tenham uma função de natureza assecuratória e, nesta perspectiva, instrumental, atuam também como direitos (tanto na dimensão subjetiva quanto na objetiva), pois investem o seu titular de uma posição subjetiva no sentido de invocar a garantia a ser favor (2015, p. 348).
\end{abstract}

Os direitos-garantia fundamentais, dessa forma, possuem uma dupla dimensão, a qual engloba a perspectiva subjetiva dos direitos fundamentais referente à possibilidade de seu titular fazer valer judicialmente poderes, liberdades, ações (positivas ou negativas) que por ele lhe foram outorgadas. Da mesma forma, uma dimensão objetiva, emanando valores objetivos 
básicos e fins diretivos das ações dos poderes públicos, implicando também em deveres de proteção do Estado (SARLET, 2015, p. 343-345).

As garantias fundamentais, de acordo parágrafo $1^{\circ}$ do artigo $5^{\circ}$ (BRASIL, 1988), possuem aplicação imediata, ou seja, não são normas de caráter meramente programático. Cabível, contudo, ressaltar que o princípio do acesso à justiça possui uma densidade normativa baixa, necessitando de uma ação normativa do legislador de forma a viabilizar a atuação do Estado na solução de conflitos dentro do direito processual (MENDES; BRANCO, 2012, p. 374-376).

Nesse sentido, o CPC de 2015 (BRASIL, 2015), que se propõe a regulamentar um processo civil constitucionalizado, também o positivou dentro do Capítulo das Normas Fundamentais, acrescentando em seu artigo $3^{\circ 5}$, algumas peculiaridades em seus parágrafos, alocando a possibilidade de realização de arbitragem e do incentivo à solução consensual dos conflitos, vinculando os operadores do Direito a utilizarem-se dos meios alternativos de resolução de conflitos (JOBIM; MACEDO, 2015, p. 52).

Dessa forma, foi confirmado, pelo legislador, que a utilização de meios alternativos de solução de conflitos (além da arbitragem) não ferem ao princípio do acesso à justiça, vez que também podem ser ferramentas efetivas para solução da pretensão no caso concreto. E tais caminhos tanto são viabilizados antes como no curso do processo, tanto assim que será objeto específico de abordagem neste trabalho a previsão de audiência de mediação ou de conciliação preliminar, antes da abertura do contraditório, quiçá como forma de quebra da quarta parede jurídica.

Após buscar o princípio no ordenamento jurídico, é necessário tentar definir seu significado e consequente abrangência. Nesse sentido, de se colacionar a lição de Cappelletti e Garth na introdução do livro "Acesso à Justiça":

\footnotetext{
A expressão "acesso à justiça" é reconhecidamente de difícil definição, mas serve para determinar duas finalidades básicas do sistema jurídico - o sistema pelo qual as pessoas podem reivindicar seus direitos e/ou resolver seus litígios sob os auspícios do Estado que, primeiro deve ser realmente acessível a todos; segundo, ele deve produzir os resultados que sejam individual e socialmente justos (2002, p. 6).
}

A primeira finalidade proposta pelos autores no parágrafo retro é a que mais se assemelha aos textos legislativos vigentes. Seguindo esse entendimento, Marinoni explica que a questão do acesso à justiça refere-se à problematização do direito de ir à juízo (seja para 
pedir a tutela de um direito ou para defender-se), partindo do pressuposto que aspectos econômicos e sociais não podem impedir o acesso à jurisdição. São proporcionadas, assim, várias garantias que objetivam dar às partes condições de efetivamente participarem do processo (2009, p. 308).

Da mesma forma, ao tratar de lesão ou ameaça de lesão do Poder Judiciário, o direito refere-se à impossibilidade de exclusão de alegação de lesão ou ameaça, tendo em vista que o direito de ação não se vincula à efetiva procedência do quanto alegado. Logo, existe independentemente de o autor ter razão em seu pleito (DIDIER JÚNIOR, 2005, p. 166). Ser ouvido e receber uma resposta é da essência do acesso à justiça. A existência de uma quarta parede é absolutamente negatória da garantia constitucional do acesso à justiça.

A partir dos conceitos trazidos, é possível concluir que o Estado, especialmente representando pelo Poder Judiciário, deve proporcionar garantias para que o sujeito que supostamente sofreu lesão ou ameaça a direito possa entrar em juízo, situação a qual não impede que o litígio seja solucionado por meios alternativos e extrajudiciais, num espaço democrático de diálogo, de participação, de integração.

Para a solução dos problemas relacionados ao acesso à justiça, que são tão remotos no tempo quanto a própria garantia, coexistindo lado a lado, Cappelletti e Garth afirmam existir três ondas, emergindo a primeira na década de 60, sucedendo-se as demais cronologicamente, mas não em caráter substitutivo e sim agregatório. A primeira onda diz respeito à assistência judiciária, instituto reconhecido às pessoas que não tenham condições financeiras. A segunda onda relaciona-se à representação dos direitos difusos (coletivos). Por fim, a terceira onda é focada nos pessoas, instituições e mecanismos utilizados para processar e até mesmo prevenir disputas. Há uma ampla variedade de reformas visando a métodos que tornem novos direitos efetivos (2002, p. 13-16).

A efetividade do acesso na primeira onda se mostra evidente com a possibilidade de concessão de assistência judiciária e jurídica gratuitas, desde que preenchidos os pressupostos. No Brasil, dois caminhos foram encontrados: o processual, reconhecendo a gratuidade dos custos processuais ao beneficiário; e o institucional, atribuindo-se ao Estado executivo o dever promocional de criar Defensorias Públicas, ambos de hierarquia constitucional.

\footnotetext{
${ }^{5}$ Art. $3^{\circ}$. [...] $\S 1^{\text {o }}$. É permitida a arbitragem, na forma da lei. $\S 2^{\circ}$ O Estado promoverá, sempre que possível, a solução consensual dos conflitos. $\S 3^{\circ}$. A conciliação, a mediação e outros métodos de solução consensual de conflitos deverão ser estimulados por juízes, advogados, defensores públicos e membros do Ministério Público, inclusive no curso do processo judicial (BRASIL, 2015).
} 
No que tange à segunda onda, tem-se, como exemplo, o ajuizamento de ações civis públicas que possibilitam a tutela de direitos difusos. Além da Lei da Ação Civil Pública (LACP) (BRASIL, 1985), esta também está prevista em leis especiais. O Estatuto do Idoso (BRASIL, 2003) é um exemplo, em seu artigo 74, inciso I, abrangendo não apenas os direitos difusos ou coletivos, mas os individuais homogêneos e os indisponíveis, vez que trata-se de grupo de pessoas especialmente protegido por lei. Tal situação também ocorre no Estatuto da Criança e do Adolescente (ECA) (BRASIL, 1990) em seu artigo 201, inciso V.

Outrossim, o Código de Defesa do Consumidor (CDC) (BRASIL, 1990), preocupado com a proteção da coletividade dos consumidores, trouxe a hipótese das ações coletivas na proteção tanto de interesses difusos e coletivos, quanto interesses individuais homogêneos. Abrange, dessa forma, inclusive situações em que o interesse é individual (com extensões próprias), mas há a possibilidade de acionamento individual.

O Estatuto do Torcedor (BRASIL, 2003) também, ao trazer a possibilidade de aplicação subsidiária do CDC, possibilitou ações coletivas relacionadas a sua matéria. Assim, para proteger o direito coletiva à higiene nos estádios, por exemplo, é possível ajuizar ação civil pública para impedir a realização de uma partida em um local que não apresente as condições adequadas. Da mesma forma, é possível a coletivização do polo passivo da ação, pois a lei impõe também aos torcedores uma série de deveres e cominações cíveis pelo seu descumprimento (OSNA, 2014, p. 243-245).

De qualquer sorte, neste trabalho, o que mais revela é a ampliação dos problemas e, consequentemente, do conceito do acesso à justiça por meio da terceira onda, porquanto o direito não é estanque e movimenta-se de acordo com a sociedade. A última onda propõe a criação de Tribunais especializados, bem como as formas alternativas de solução de conflitos. É preciso, assim, pensar num processo constitucionalizado e, consequentemente, em maior abrangência do princípio do acesso à justiça. Foram possibilitados meios de ajuizamento de ações pelas pessoas que não possuem condições financeiras, igualmente, a representação de interesses difusos e coletivos, por meio das duas primeiras ondas. Como preocupação da terceira onda no contexto atual do direito, em especial do processo, há a efetividade na prestação jurisdicional, que também engloba o acesso à justiça. Não basta a possibilidade de ajuizar a ação, o direito deve ser efetivo por meio de numa atuação mais ativa dos jurisdicionados. 


\section{A QUEBRA DA QUARTA PAREDE COMO FORMA DE EFETIVAÇÃO DO ACESSO À JUSTIÇA}

Compreender o conceito de um princípio e de seu papel no ordenamento jurídico não é tarefa fácil, especialmente quando se vive a tradição do princípio da legalidade, constitucionalizado no artigo $5^{\circ}$, inciso II, da CRFB (BRASIL, 1988), o que também obriga o intérprete a compreender o equilíbrio entre princípios a serem adotados, e sua respectiva proporcionalidade.

Os princípios e as regras fazem parte da norma, vez que dizem respeito a razões para juízos concretos do dever ser. A distinção entre ambos pode se valer de vários critérios, tal como a generalidade, porquanto princípios são normas com grau de generalidade relativamente alto. A partir de tais premissas, Robert Alexy traz três teses diversas acerca da distinção, elegendo a hipótese de que não há uma diferença gradual, mas sim qualitativa entre ambos. Os princípios são mandamentos de otimização, os quais podem ser satisfeitos em graus variados, dependendo das suas possibilidades fáticas e jurídicas; diferentemente das regras, as quais são sempre satisfeitas ou não (2008, p. 86-91).

Demarcada, em apertada síntese, a diferenciação entre princípios e regras, cabível analisar conceito de norma e visualisar claramente sua distinção em relação ao texto legal. As normas são os sentidos construídos a partir da interpretação sistemática dos textos normativos. Destarte, a atividade do jurista, assim como a do cientista, é construir os significados dos textos, dentro de determinados limites (ÁVILA, 2005, p. 22-24).

Para aplicação do princípio do acesso à justiça ao caso concreto, é necessária a construção de um significado do texto, por meio da interpretação, recebendo influência das possibilidades fáticas e jurídicas que permeiam a situação. Assim, utilizando-se da expressão de Marinoni, antes mencionada, de que o acesso à justiça deve dar condições para que os jurisdicionados efetivamente participem do processo, bem como analisando o amplo conceito utilizado por Cappelletti e Garth ao tratarem da terceira onda como forma de sanar os problemas relacionados ao referido processo, é possível entender que o litigante, para ver efetivada essa situação, necessita realmente fazer parte do processo, deixando de ser mero espectador, o qual não interage e muitas vezes nem entende o que se passa com seu direito a ser tutelado. 
Propõem-se, destarte, a quebra da quarta parede que isola o jurisdicionado dos demais operadores do direito. Cabível, entretanto, ressaltar que as partes não podem sutrair os papéis do advogado, promotor ou julgador. Assim como ocorre no mundo do teatro, nenhum deixa de ser o que é, mas é possibilitada uma interação entre todos. A seguir, serão explorados meios facilitadores para que ocorra esse rompimento, ainda que sem esgotar o tema, pondo em destaque apenas alguns desses mecanismos, em especial, a audiência do artigo 334 do CPC (BRASIL, 2015).

\subsection{A simplificação da linguagem}

É de conhecimento amplo e notório que a linguagem jurídica tende a ser mais complexa e rebuscada. A Associação Brasileira dos Magistrados (ABM) já realizou campanhas pela simplificação da linguagem jurídica ${ }^{6}$. Da mesma forma, está em tramitação o Projeto de Lei $n^{\circ} 7.448 / 2006^{7}$ (BRASIL, 2006), o qual prevê a elaboração de sentenças de forma simples, clara e direta, por meio da alteração do inciso III do artigo $458^{8}$ do antigo CPC (BRASIL, 1973), o qual passaria a vigorar com a seguinte redação, "o dispositivo, em que o juiz resolverá as questões, que as partes lhe submeterem, redigido de maneira acessível a elas".

Um dos grandes entraves para o entendimento dos jurisdicionados e que, consequetemente, os ditancia do processo é a linguagem excessivamente ornamentada dos operadores do direito. Durante uma audiência, a plateia, composta por partes e testemunhas, assiste aos atores do direito enquanto estes, em sua maioria, proferem palavras inintelígiveis aos ouvidos leigos, as quais estão diretamente ligadas ao futuro de sua pretensão.

Ora, para a quebra da quarta parede, é necessária a simplificação dos termos utilizados com os jurisdicionados, que são, afinal, os principais, se não únicos, destinatários dos pronunciamentos. Afinal, o mérito da sentença interessa mais aos litigantes do que aos seus procuradores e aos demais operadores do direito.

\footnotetext{
${ }^{6}$ Foi lançada em 2005 campanha, pela ABM, para simplificar a linguagem jurídica utilizada por magistrados, advogados, promotores e outros operadores da área. Disponível em: <http://www.amb.com.br/index_.asp?seca o=campanha_juridiques $>$. Acesso em: 23 mar. 2016.
} 


\subsection{Juizados Especiais}

Os Juizados Especiais Cíveis foram instaurados, em 1995, pela Lei n. 9.099 (BRASIL, 1995), priorizando os princípios oralidade, simplicidade, informalidade, economia processual e celeridade, bem como incentivando os meios alternativos de solução de litígios. Em 2001, aumentou-se o âmbito de abrangência de tais juizados para Justiça Federal, por meio da Lei n. 10.259 (BRASIL, 2001).

A terceira onda de Cappelletti e Garth demonstra a preocupação também com a criação de tribunais especializados, tornando os processos mais acessíveis, menos dispendiosos e morosos, bem como melhor adaptados à complexidade dos litígios, tornando a Justiça mais justa e acessível. Em decorrência dessa situação, para que os direitos das pessoas comuns não permanecessem meramente simbólicos, foram criados os Juizados Especiais (INATOMI, 2009, p. 34-36).

É um procedimento, assim, que busca à quebra da quarta parede e, consequentemente, visa à efetivação do princípio do acesso à justiça. Além de possuir uma linguagem simplificada na relação dos operadores do direito com os jurisdicionados, o advogado é elemento facultativo no ajuizamento e defesa da lide, o que possibilita uma parte mais ativa e que consegue melhor entender o desenvolvimento do processo. Ademais, a Lei n. 9.099 (BRASIL, 1995) estabelece que a audiência de conciliação será agendada independemente do processo já estar distribuído e autuado.

\subsection{As audiências de conciliação}

A conciliação é um meio alternativo de resolução de conflitos em que as partes, com o auxílio de uma terceira pessoa (conciliador), buscam solucionar determinado litígio por meio de um acordo construído por ambas. No caso da audiência de conciliação, esta ocorre quando a lide já foi ajuizada.

\footnotetext{
${ }^{7}$ Conforme tramita no sítio eletrônico do Congresso Nacional. Disponível em: <http://www.camara.gov.br/propo sicoesWeb/fichadetramitacao?idProposicao=333090>. Acesso em: 23. mar. 2016.

8 A proposta de lei é anterior ao CPC vigente (Lei n. 13.105/2015), transportando à atualidade, a redação alterada do CPC de 2015 seria o inc. III do art. 489.
} 
O artigo 334 do CPC de 2015 (BRASIL, 2015) trouxe a obrigatoriedade da audiência de conciliação (ou mediação, lembrando que ambos não são termos sinônimos) preliminar, salvo se ambas as partes manifestarem expressamente o desinteresse ou a situação não comportar a autocomposição. Tais formas de autocomposição, contudo, já estavam previstas em legislações anteriores, mesmo que sem caráter tão incisivo.

O artigo 331 do CPC de 1973 (BRASIL, 1973) já previa a possibilidade de uma audiência preliminar que buscava a solução conciliatória, antes da audiência de instrução e julgamento, desde que o direito admitisse transação. Nesse sentido, o artigo 447 também previa a conciliação quando o litígio versasse sobre direitos patrimoniais privados. $\mathrm{O}$ acordo homologado pelo juiz detinha inclusive a força de título executivo judicial, nos termos do inciso III, do artigo $475-\mathrm{N}$.

A possibilidade de audiência de conciliação, no caso da ação de alimentos, é regulada pela Lei 5.478 (BRASIL, 1968), anterior ao CPC de 1973 (BRASIL, 1973). O artigo $9^{\circ}$ dispõe que o juiz ouvirá as partes litigantes e o Ministério Público, propondo a conciliação. Caso não ocorra o acordo, prosseguirá com a audiência de instrução e julgamento, colhendo os depoimentos pessoais e ouvindo as testemunhas.

Há, dessa forma, um incentivo para os meios alternativos de resolução de conflitos. Nesse sentido, Mauro Cappelletti manifesta-se:

\footnotetext{
Essa ideia decerto não é nova: a conciliação, a arbitragem, a mediação foram sempre elementos importantes em matéria de solução de conflitos. Entretanto, há um novo elemento consistente em que as sociedades modernas descobriram novas razões para preferir tais alternativas. É importante acentuar que essas novas razões incluem a própria essência do movimento de acesso à Justiça, a saber, o fato de que o processo judicial agora é, ou deveria ser, acessível a segmentos cada vez maiores da população, aliás, ao menos teoricamente, a toda a população. Esse é sem dúvida o preço do acesso à Justiça, o qual é o preço da própria democracia: um preço que as sociedades avançadas devem sentir-se dispostas a (e felizes em) pagar ( 2014, p. 410).
}

Após a análise breve da existência de audiências de conciliação positivadas antes do Código de Processo Civil de 2015, faz-se necessário o estudo específico do artigo 334 da referida lei como forma de quebra da quarta parede e, consequente, meio de efetivação do princípio do acesso ao poder judiciário. 


\section{A AUdiênCIA do ARTigo 334 do Código de PROCESSO CIVIL DE 2015: UMA POSSIBILIDADE DE QUEBRA DA QUARTA PAREDE?}

Obstáculo que se põe para romper com os pré-conceitos e construir um novo paradigma para um determinado instituto é o do próprio intérprete que carece de se reinventar, olhando o novo com olhos de novo e não com um olhar pretérito, conservador, mantenedor do status quo.

Não é de hoje que se estimula a autocomposição nos conflitos, mas sua aceitação pelos destinatários (operadores e jurisdcionados) de tais propostas não tem sido fácil e muito menos mostra-se alvissareira.

O novo CPC (BRASIL, 2015) propõe uma reformulação dessa alternativa, revitalizandoa. Em harmonia com as regras fundamentais, antes analisadas, objeto de seu artigo $3^{\circ}$, o legislador processual impôs aos órgãos do Poder Judiciário a criação de centros judiciários de solução consensual de conflitos, conforme artigo 165, responsáveis pelas audiências ou sessões de conciliação e mediação, bem como por instituir programas destinados a auxiliar, orientar e estimular a autocomposição. Já por aí se vê a necessidade de consolidar a proposta alternativa através de ações afirmativas, ampliando o espectro de operadores que deverão atuar neste cenário de consenso e não de adversariedade. Tal previsão legislativa passa a configurar adoção de uma política pública de busca de consenso nos conflitos, vinculando não apenas os órgãos do Poder Judiciário, mas também outros órgãos públicos, como o Ministério Público e a Defensoria Pública e, no âmbito do processo administrativo, conforme dispõe o artigo 174, às esferas executivas federal, estadual e municipal.

De qualquer sorte, nos limites deste trabalho, centra-se a discussão na audiência do artigo 334 do Código.

\subsection{A audiência (de mediação) do artigo 334 e sua cogência: críticas e encômios}

O texto do artigo 334 do novo CPC (BRASIL, 2015), como está posto, sugere a cogência de uma audiência preliminar, independentemente da demanda posta, que poderá ser ou de mediação ou de conciliação. Neste tópico, atentar-se-á exclusivamente à audiência de mediação, ainda que algumas referências possam ser levantadas em realização à audiência de conciliação. 
Esta cogência decorre do disposto no $\S 4^{\circ}$ do mesmo artigo, que contempla duas hipóteses para a sua não ocorrência: $a$ ) quando ambas as partes manifestarem desinteresse na autocomposição, e $b$ ) quando não se admitir a autocomposição.

Para a primeira hipótese, cumpriria ao autor desde logo expressar seu desinteresse na petição inicial e ao réu, quando citado, apresentar petição no prazo de 10 (dez) dias de antecedência, ou seja, a audiência já estaria designada, até porque integraria o despacho inicial de recebimento da petição inicial $\left(\S 5^{\circ}\right)$. Por outro lado, o $\S 8^{\circ}$ considera ato atentatório à dignidade da justiça, sancionado com multa de até dois por cento da vantagem econômica pretendida ou do valor da causa, revertida em favor da União ou do Estado.

Nesse sentido, a Escola Nacional de Formação e Aperfeiçoamento de Magistrados (ENFAM), em seminário realizado sobre o novo $\mathrm{CPC}$, editou enunciados, entre os quais o de n. 61 , assim redigido:

Somente a recusa expressa de ambas as partes impedirá a realização da audiência de conciliação ou mediação prevista no art. 334 do CPC/2015, não sendo a manifestação de desinteresse externada por uma das partes justificativa para afastar a multa de que trata o art. 334, $\S 8^{\circ}$ (BRASIL, 2015).

Há, portanto, uma convergência entre o disposto na lei e o entendimento prévio manifestado por órgão da magistratura para se ter a audiência preliminar como cogente. E a doutrina segue no mesmo caminho:

[...] Portanto, ao contrário do CPC de 1973, não pode o juiz dispensar a realização da audiência por seu livre-arbítrio no caso de improbabilidade de conciliação entre as partes. A audiência ocorrerá obrigatoriamente, salvo nos casos que não admitam transação e quando todas as partes manifestarem, expressamente, o seu desinteresse (RIBEIRO; FISCHER, 2015, p. 58).

Considerando, destarte, que a lei não distingue se a audiência será de mediação ou de conciliação, aplica-se tal cogência a ambas as hipóteses. Aqui reside a primeira crítica a ser oportunamente deduzida.

De qualquer sorte, voltando, ainda, às hipóteses de dispensa da audiência prévia, temse o segundo caso, relativo à não admissão de autocomposição. Como bem destaca Fredie Didier Júnior (2015, p. 625) não há que confundir direitos indisponíveis com impossibilidade de autocomposição, exemplificando o jurista como hipótese incidente aquelas em que o Poder Público é parte no conflito e não está autorizado para a composição, ainda que o novo estatuto 
processual também estimule a autocomposição em processos administrativos ou judiciais, em que for parte o poder público, como antes já sinalizado. Pode-se agregar, ainda, conflitos que digam com direitos de personalidade, como demanda que envolva o nome da parte ou o estado de capacidade. Isso sob o aspecto de vedação formal. Nada impede, porém, especialmente na hipótese de direitos de personalidade, que a parte demandada anua ao pedido, com ele concordando expressamente, na forma prevista pelo artigo 487, inciso III, alínea $a$, do CPC (BRASIL, 2015), o que, por si só, resultaria na supressão da audiência, mas de certa forma alcançando o mesmo objetivo: afastar o conflito.

Para além desses casos, ainda que não expressamente previsto no texto em comento, pode se levar em conta que determinadas demandas não estão materialmente afeitas à autocomposição. Cita-se aqui, como exemplo, ações repetitivas, no mais das vezes responsáveis pelo fenômeno da numerosidade de processo, principal responsável pela intempestividade do processo e inefetividade da prestação jurisdicional. O conflito é subjetivamente muito maior do que os limites individuais, autor e réu, pois, ainda que se alcance uma composição consensual em relação àquele sujeito individualmente posto na relação processual, o conflito se repete para além daquele processo pontual, fazendo-se presente a necessidade de uma composição coletiva, seja consensual, seja por força de decisão judicial que atinja toda a coletividade. Não é por outra razão que o novo CPC (BRASIL,

2015) adotou, com todas as letras, o precedente vinculante para demandas tais. Há de indagar se, efetivamente, vem ao encontro do interesse público, nesses casos, eventual transação pontual, que até pode, ainda que de difícil sucesso, alcançar o interesse individual da parte, mas jamais a defesa da própria ordem jurídica, incontestavelmente entregue ao Poder Judiciário, porque eventual dano ou ilícito a ensejar a tutela perseguida (e alcançada em termos pelo consenso pontual) persistiria aos demais sujeitos não integrantes daquela lide individual. $\mathrm{O}$ que se quer desnudar é que nos conflitos repetitivos a necessidade de superar a quarta parede, promovendo a plena integração entre os atores (agentes públicos no exercício da jurisdição) e os espectadores (os juridicionados) não pode se esgotar na interação com um ou dois dos espectadores, excluindo-se os demais.

De concluir, portanto, que mesmo a regra da exceção acusa uma certa inconsistência, ora afastando da audiência demanda que poderia resultar em consenso, ora não excluindo grupo de demandas cuja composição seria de no mínimo discutível utilidade. 
Mas, quiçá, o ponto crucial diz com a generalização da previsão da audiência preliminar de mediação, colocando-a par a par com a conciliação, o que será melhor explorado adiante.

\subsection{Generalização da previsão da audiência preliminar de mediação}

A par das críticas deduzidas, o fato é que a cogência de realização de audiência de mediação, prevista para a mais absoluta generalidade de hipóteses de conflito, vem ao desencontro dos princípios que regem a mediação, em especial a isonomia entre as partes, a autonomia da vontade das partes e a busca do consenso.

Nos termos em que está redigido o artigo 334 (BRASIL, 2015), mais parece uma busca de solução para o fenômeno da numerosidade de processos, que atingiu no ano de 2015 o número fabuloso de 9 (nove) dígitos ${ }^{9}$, aliviando-se a pauta de processos litigiosos mas esquecendo-se o legislador processual que os principais responsáveis pelo excesso de litigiosidade são os conflitos repetitivos, envolvendo grandes fornecedores de crédito, produtos e serviços, e o próprio poder público, de todos, os menos sensíveis à autocomposição. Tais grupos, de regra, atuam movidos pela estatística agregada à obtenção de vantagens e não pelos critérios de justiça e de respeito à ordem jurídica, atuando em planos e com objetivos que os afastam da condição de meros expectadores (ou jurisdicionados), a despeito do disposto no artigo $5^{\circ}$, inciso XXXV, da CRFB (BRASIL, 1988).

Sem embargo, contudo, de poder ser prevista uma audiência preliminar de conciliação, a ser realizada pelo próprio juiz (de lembrar a realidade judiciária em todos os confins do território nacional e as enormes dificuldades de organização judiciária em compor tais quadros) ou por centros de conciliação compostos por conciliadores para tanto devidamente formados e preparados (artigos 165 e seguintes), até porque a conciliação é atividade ínsita à prestação jurisdicional, de velha tradição no processo civil. Trata-se de proposta que merece encômios, inclusive com relação à sua cogência, porque se trata de construir um novo modelo de processo, mais consensual, menos adversarial.

\footnotetext{
${ }^{9}$ Campanha lançada pelo CNJ denominada de "Processômetro". Disponível em: <www.agencia-brasil.jusbrasil.c om.br/noticias/1626777/cnj-lanca-processometro-para-divulgar-e-acompanhar-trabalho-dos-tribunais $>$. Acesso em: 24 mar. 2016.
} 
O Direito não é apenas fruto da cultura, é também seu indutor. As práticas de solução de conflitos são tanto refléxicas quanto construtivas da cultura, pois há uma conexão profunda entre ambos. As instituições de resolução de conflitos acaba sendo produto e colaborador dos aspectos culturais. Necessário, dentro do contexto, considerar a vagueza do conceito de cultura, relacionando-o com as ideias, valores e normas tradicionais amplamente compartilhados em um grupo social (CHASE, 2014, p. 21-23).

Cediço que a mediação - importante espaço democrático de autocomposição de conflitos - não representa remédio para todos os males que afetam ao Poder Judiciário, voltandose para determinadas classes de conflitos, não para a generalização de feitos que assola os foros de primeiro grau de jurisdição. Representa, sim, um marco democrático na composição de conflitos, mas utilizar a mediação para sanar as deficiências administrativas, de organização judiciária ou do próprio sistema processual, que não conta com freios efetivos ao abuso da litigiosidade (outro problema que não pode ser ignorado), não é a melhor solução, mais representando uma troca de seis por meia dúzia.

\subsection{Opção entre mediação e conciliação: critérios}

Independentemente da crítica à generalização da audiência preliminar, agrega-se a indispensável tomada de posição: remetem-se as partes para a mediação ou para a conciliação? O que define o encaminhamento para uma ou para outra forma de autocomposição? E se remetida as partes para a mediação, quando mais compatível seria a conciliação, ou viceversa, não representaria isso uma perda de tempo, em dissonância com o propósito de obter-se a solução integral do mérito em prazo razoável (artigo 4º CPC) (BRASIL, 2015)?

Comportaria às partes a escolha? Em qual momento? Petição inicial, por conta do autor? $\mathrm{Na}$ manifestação do prazo em 10 (dez) dias, valendo-se o réu não da resistência à autocomposição, mas optando por uma ou por outra via, em desacordo com a manifestação do autor? E, em havendo dissonância entre as partes, o que há de prevalecer ${ }^{10}$ ? Seria viável as partes, presentes à primeira audiência, pedirem o encaminhamento para a outra via de autocomposição?

\footnotetext{
${ }^{10}$ Tais indagações mostram que o texto legal também pode representar um distanciamento de seus destinatários, não sendo demasia levantar-se o mesmo questionamento, qual seja, a quarta parede que se estabelece entre egislador e destinatário da norma! De qualquer forma, tal investigação exigiria espaço próprio que o presente trabalho não autoriza, ficando aqui mais como uma reflexão ao leitor.
} 
No artigo 165, mais precisamente nos $\S \S 2^{\circ}$ e $3^{\circ}$, do CPC (BRASIL, 2015), orienta-se a opção entre uma ou outra forma de composição consensual do conflito a partir da existência ou não de vínculo anterior entre as partes. Versando a demanda sobre conflito decorrente de vínculo jurídico pré-existente (leia-se, relação jurídica), estimula-se a mediação; se o conflito decorre de situação jurídica (a exemplo, conflitos envolvendo responsabilidade extracontratual ou decorrentes de direitos potestativos, podendo também aqui se incluir os conflitos decorrentes do ilícito civil), o caminho mais viável seria a conciliação.

A diferença é tênue e o próprio legislador a adverte valendo-se da expressão "preferencialmente". Nada impede que haja conciliação num conflito que procura compor relação jurídica pré-existente, tenha ela ou não se esgotado no tempo, e o inverso também, isso é, haver mediação quando o conflito alimenta-se de uma situação jurídica.

Ou seja, o formato proposto, a uma, não afasta a possibilidade de crise no processo, abrindo-se debates paralelos ao debate principal, consubstanciado esse no conflito a ser composto; a duas, não estimula a integração entre os personagens e o público, mantendo uma parede invisível que poderá ser danosa para a concretização de um modelo de processo consensual.

O que se propõe, em apertada síntese, é a participação efetiva dos destinatários, maiores interessados na composição do conflito, na definição dos rumos do processo e das vias de solução, vencendo-se a quarta parede.

Indispensável, nesse ponto, que o Código de Processo dialogue com a Lei da Mediação, o que, parece, não ocorrreu.

\subsection{A Lei n. 13.140/2015}

O instituto da mediação veio recentemente regulado pela Lei n. 13.140/2015 (BRASIL, 2015), publicada em data de 29/06/2015, cujo prazo de vigência previsto para 180 (cento e oitenta) dias após sua publicação, isto é, dia 26/12/2015, e, portanto, antes mesmo de entrar em vigência o novo CPC (BRASIL, 2015).

Indispensável, portanto, conciliar os dois estatutos - a Lei da Mediação e o CPC - em especial no que diz com a audiência preliminar do artigo 334 do CPC (BRASIL, 2015). 
Sem pretender aprofundar a compreensão e a reflexão sobre o instituto da mediação até porque foge ao objeto deste trabalho - ponto fundamental a ser destacado vem no parágrafo único do artigo $1^{\circ}$ da lei de regência: o mediador não detém poder de decisão. São as partes que devem encontrar a solução consensual sobre a controvérsia, ou seja, o poder de decisão lhes compete. Por isso mesmo, princípio condutor da mediação, entre outros, é o da autonomia da vontade das partes, que para tanto devem guardar paridade, o que desagua em outro princípio do instituto, que é a isonomia. Tais vetores encontram-se expressamente previstos no artigo $2^{\circ}$, da Lei n. 13.140 (BRASIL, 2015). Como corolário, o $\S 2^{\circ}$ deste dispositivo assegura que "ninguém será obrigado a permanecer em procedimento de mediação". Ou seja, basta que um dos conflitantes rejeite a mediação e ela estará prejudicada.

Outro traço fundamental é que a mediação deve ter por objeto conflito que verse sobre direitos disponíveis ou sobre direitos indisponíveis que admitam transação (artigo $3^{\circ}$ ). Ou seja, há conflitos que não guardam aderência à autocomposição, especialmente aqueles que integram o patrimônio jurídico da pessoa humana como os direitos de personalidade. Forçoso concluir que a mediação não é solução para todos os conflitos de interesses.

O estatuto da mediação cria, por outro lado, a figura de mediadores judiciais - o que encontra harmonia com as disposições do CPC (BRASIL, 2015) ao prever os centros judiciários de solução consensual de conflitos - e a de mediadores extrajudiciais, que há de ser objeto de contrato, nos termos dos artigos 21 a 23 da respectiva lei de regência, ambas as atuações, porém, voltadas para a definitividade do conflito: título executivo extrajudicial ou título executivo judicial, conforme o caso (artigo 20, parágrafo único).

Sem adentrar no procedimento específico da mediação, vale ressaltar que desde logo o estatuto prevê a realização de sessões sucessivas (artigos 14 e 18), até porque se trata de um processo onde se trabalha psicologicamente a assimilação do próprio conflito, de sua origem e extensão, das possíveis consequências, que cumpre às partes irem construindo até chegarem a um denominador comum. A mediação não objetiva um vencedor, mas que não haja perdedores, orientando-se não pelo critério da justiça, mas sim do interesse.

Tais premissas fazem concluir, já num primeiro momento, que na mediação os principais agentes são os próprios contendores, que passam a ser o foco dos refletores, ficando o papel do mediador para um segundo plano, mais comparecendo como um provocador de hipóteses, sinalizando as possíveis consequências de um ou de outro caminho a ser trilhado por escolha dos contendores. Não há, na mediação, assim estruturada, uma quarta parede, pautando-se sua 
realização pela integração e ação direta dos envolvidos que se colocam frente à frente, construindo numa conjugação de esforços a solução comum.

Só por aí se vê que não há tratar pelos mesmos cânones a mediação e o processo judicial, com ou sem conciliação, essa sim inerente, mas não exclusiva, da atividade processual, embora se perceba uma forte tendência de judicialização da mediação, tanto na Lei n. 13.140/2015 como no próprio CPC (BRASIL, 2015), tema, porém, que foge aos limites deste artigo.

O fato é que a banalização e a igualização no trato das audiências de mediação e conciliação dadas pelo artigo 334, por vezes afastando-se da essência da mediação, devem ser trabalhadas para que a proposta comprometida com o processo consensual não traia os seus objetivos. E, dentre esses objetivos, a derrubada da quarta parede, até porque o comprometimento das partes na autocomposição evita o desgaste e, por vezes, ausência de legimidade das decisões judiciais, sabidamente submetidas a sucessivas e subsequentes fases procedimentais, como a incidência de recursos, impugnações ao cumprimento da sentença, propositura de novas ações.

\section{A GUISA DE CONSIDERAÇÕES FINAIS: AUDIÊNCIA DE AUTOCOMPOSIÇÃO COMO ESTRATÉGIA DEMOCRÁTICA DO PROCESSO}

O processo não pode mais ser pensado à luz da técnica e das formas, como mero instrumento de realização da jurisdição.

Jurisdição e processo, democracia e concretização da ordem jurídica não são expressões que se perfectibilizam num esquema de prazos, atos, formas, ritos e procedimentos. Por certo que a técnica também se faz necessária, mas como meio, não como um fim em si própria. A jurisdição e o processo constituem espaço democrático de realização dos direitos fundamentais, entre os quais o próprio acesso à Justiça, bem com asseguram (ou devem assegurar) a tutela adequada aos direitos, individuais ou coletivos, subjetivos ou sociais, cuja exigibilidade e efetivação carecem da intervenção do Estado-juiz.

A audiência de autocomposição que o artigo 334 do CPC (BRASIL, 2015) impôs à regularidade procedimental do processo civil não pode ser vista como mera formalidade. Seu acontecimento deve ser um momento máximo de participação direta, conforme o parágrafo único do artigo $1^{\circ}$ da CRFB (BRASIL, 1988), dos sujeitos do processo, que deixam de ser, 
neste momento, sujeitos para se tornarem agentes, pessoalmente responsáveis pela construção da composição e superação do conflito, legitimando integralmente a solução encontrada. Configura um dos pilares do novo paradigma processual, daí porque deduzir e superar possíveis inconsistências legislativas, ao efeito de aperfeiçoar a proposta, para que ela não redunde em mera formalidade, neutralizando com práticas pretéritas, talvez até bem intencionadas mas fracassadas, o que ela propõe de novo, aqui abordando tanto a mediação como a conciliação.

Trata-se, pois, de uma clara estratégia que assegura a democracia no processo, onde não há uma parede distanciando os atores do público. Há, mais que isso, uma absoluta integração entre os agentes responsáveis pela composição do conflito, onde o público (jurisdicionado) torna-se, na verdade, o principal protagonista do enredo, embora não significando em si uma troca de papeis, redigindo, montando, ajustando o desenlace ao efeito de vencer o impasse do conflito, enquanto que os representantes do Estado - na origem, o(s) ator(es) - assumem a condição de partícipes, de fomentadores, de fiscalizadores e auxiliares na construção da autocomposição. 


\section{REFERÊNCIAS BIBLIOGRÁFICAS}

ALEXY, Robert. Teoria dos direitos fundamentais. Tradução de Virgílio Afonso da Silva. São Paulo: Malheiros, 2008.

ÁVILA, Humberto. Teoria dos princípios: da definição à aplicação dos princípios jurídicos. 4. ed. São Paulo: Malheiros, 2005.

CAPPELLETTI, Mauro. Os métodos alternativos de solução de conflitos no quadro do movimento universal de acesso à justiça. Revista de Arbitragem e Mediação, São Paulo, v. 444, p. 405-423, abr./jun. 2014.

2002.

; GARTH, Bryant. Acesso à justiça. Porto Alegre: Sérgio Antonio Fabris Editor,

CHASE, Oscar G. Direito, cultura e ritual: sistemas de resolução de conflitos no contexto da cultura comparada. Tradução de Sérgio Arenhart e Gustavo Osna. São Paulo: Marcial Pons, 2014.

DIDIER JÚNIOR, Fredie. Curso de direito processual civil. Salvador: JusPodivm, 2015. v. 1 .

Direito à inafastabilidade do poder judiciário.In: LEÃO, Adroaldo; PAMPLONA FILHO, Rodolfo (coord.). Direitos constitucionalizados. Rio de Janeiro: Forense, 2005. p. 165-175.

INATOMI, Celly Cook. O acesso à justiça no Brasil: a atuação dos juizados especiais federais cíveis. 2009. 176 f. Dissertação (Mestrado em Ciência Política) - Instituto de Filosofia e Ciências Humanas, Faculdade Estadual de Campinas, 2009.

JOBIM, Marco Félix; MACEDO, Elaine Harzheim. Das normas fundamentais do processo e o projeto de novo Código de Processo Civil brasileiro: repetições e inovações. In: RIBEIRO, Darci Guimarães; JOBIM, Marco Félix (orgs.). Desvendando o novo CPC. Porto Alegre: Livraria do Advogado, 2015, p. 43-57.

MANGAN, Michael. The drama, theatre and performance companion. Londres: Palgrave Macmillan, 2013.

MARINONI, Luiz Guilherme. Teoria geral do processo. 3. ed. rev. e atual. São Paulo: Editora Revista dos Tribunais, 2009. v. 1. 
MENDES, Gilmar Ferreira; BRANCO, Paulo Gustavo Gonet. Curso de direito constitucional. 7. ed. rev. e atual. São Paulo: Saraiva, 2012.

MEZZAROBA, Orides; MONTEIRO, Cláudia Sevilha. Manual de metodologia da pesquisa no direito. 6. ed. São Paulo: Saraiva, 2014.

MIRANDA, Rita Alves. Estudos sobre Bertolt Brecht. Existência e Arte - Revista Eletrônica do Grupo PET, São João Del-Rei, v. 7, n. 6, p. 25-41, jan./dez. 2011.

OSNA, Gustavo. As ações coletivas e o Estatuto de Defesa do Torcedor - o processo civil clássico na marca do pênalti. Revista de Processo, São Paulo, v. 232, p. 239-259, jun. 2014.

PORTO, Sérgio Gilberto. Comentários aos artigos $1^{\circ}$ a 12. In: MACEDO, Elaine Harzheim (org.). Comentários ao projeto de lei n. 8.046/2010: proposta de um novo código de processo civil. Porto Alegre: EDIPUCRS, 2012, p. 23-32. Disponível em: < http://ebooks.pucrs.br/edipucrs/Ebooks/Pdf/978-85-397-0300-5.pdf>. Acesso em: 15 mar. 2016.

RIBEIRO, Cristiana Zugno Pinto; FISCHER, Roger. A audiência de conciliação ou de mediação no novo CPC. In: TESHEINER, José Maria; MACEDO, Elaine Harzheim; THAMAY, Rennan Faria Krüger (orgs.). Procedimento comum: da petição inicial à sentença. Curitiba: Juruá, 2015, p. 41-64.

SARLET, Ingo Wolfgang. Teoria geral dos direitos fundamentais. In: ; MARINONI, Luiz Guilherme; MITIDIERO, Daniel. Curso de direito constitucional. 4. ed. atual. e ampl. São Paulo: Revista dos Tribunais, 2015, p. 295-395. 